\title{
S2 Figure
}

A

CD4 gate within
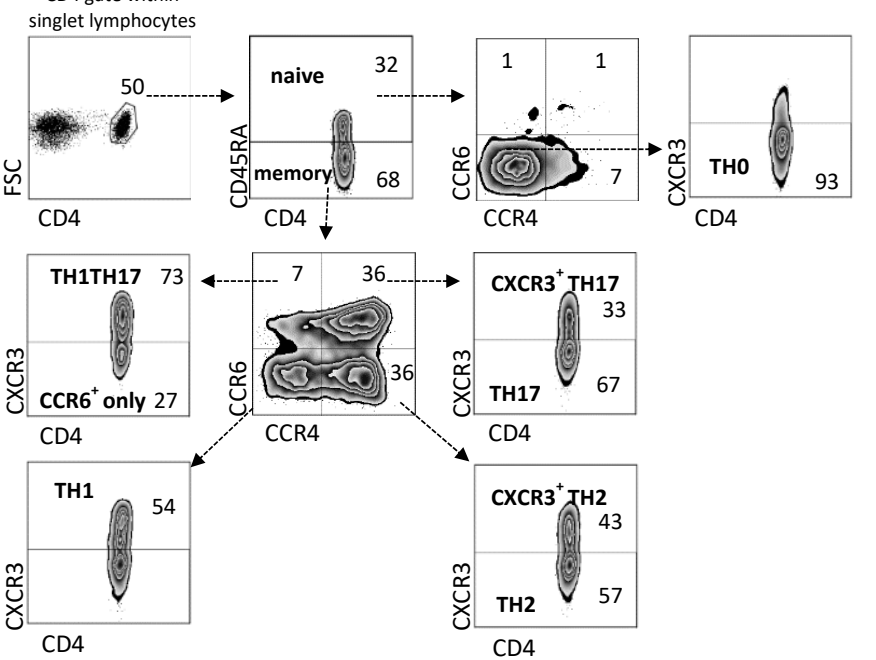

B
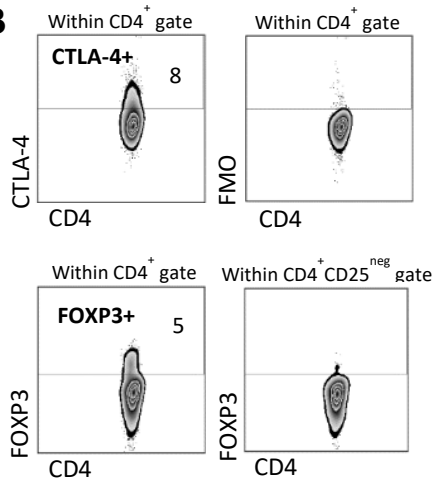

C Within $\mathrm{CD}^{+}$gate
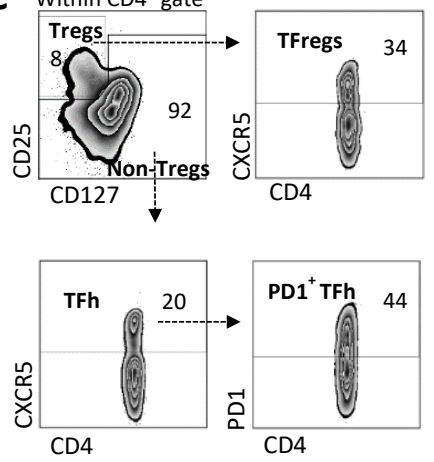

Fig S2. Gating strategy of CD4+ T cell subsets previously published in Aldridge et al (Arthritis Research and Therapy 2018, 20:150). The gating strategy (from a representative female RA patient) was as follows: (a) singlet PBMCs were gated for lymphocytes and then further gated for $\mathrm{CD}^{+} \mathrm{T}$ cells. $\mathrm{CD}^{+}$cells where then divided into naïve $\left(C D 45 \mathrm{RA}^{+}\right)$and memory $\left(C D 45 R A^{\text {neg }}\right)$ subsets. From naïve cells, CCR4 ${ }^{\text {neg }} C C R 6^{\text {neg }} C X C R 3^{\text {neg }}$ cells were defined as Th0. Memory cells were divided into four subsets based on CCR4 and CCR6 expression, each of which was the further divided based on CXCR3 expression; Th1 (CCR4 $\left.{ }^{\text {neg }} C C R 6^{\text {neg }}{ }^{C X C R 3} 3^{+}\right), \quad$ Th2 $\quad\left(C C R 4^{+} C C R 6^{\text {neg }} C X C R 3^{\text {neg }}\right), \quad$ CXCR3 ${ }^{+}$Th2

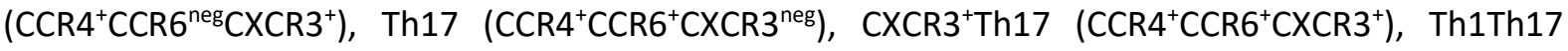
(CCR4 $\left.{ }^{\text {neg }} \mathrm{CCR} 6^{+} \mathrm{CXCR} 3^{+}\right)$, and CCR6 ${ }^{+}$only (CCR4 ${ }^{\text {neg }} \mathrm{CCR} 6^{+} \mathrm{CXCR} 3^{\text {neg }}$ ). (b) The cutoff for CTLA-4 positivity on $\mathrm{CD}^{+} \mathrm{T}$ cells were determined using fluorescence minus one (FMO) and cutoff for FOXP3 positivity in $\mathrm{CD} 4^{+}$cells was based on FOXP3 expression in $\mathrm{CD} 25^{\text {neg }}$ gated $\mathrm{CD} 4^{+}$cells. (c) Regulatory T cells (Tregs) were defined by $\mathrm{CD} 25^{+} \mathrm{CD} 127^{\text {low }}$ expression, while the remaining cells were defined as non-Tregs. CXCR5 ${ }^{+}$Tregs were defined as follicular regulatory T cells (TFregs) and CXCR5 ${ }^{+}$non-Tregs as follicular helper T cells (TFh). 